\title{
Response of phytoplankton assemblages to nitrogen reduction in the Laizhou Bay, China
}

\author{
Huichao Jiang ${ }^{\mathrm{a}, \mathrm{b}, \mathrm{c}}$, Dongyan $\mathrm{Liu}^{\mathrm{a}, \mathrm{d}, *}$, Xiukai Song ${ }^{\mathrm{c}}$, Yuanqing $\mathrm{Ma}^{\mathrm{c}}$, Yujue Wang ${ }^{\mathrm{a}}$, Aiying Liu ${ }^{\mathrm{c}}$, \\ Ling Cheng ${ }^{c}$, Jianlong $\mathrm{He}^{\mathrm{c}}$, Shan Sun ${ }^{\mathrm{c}}$

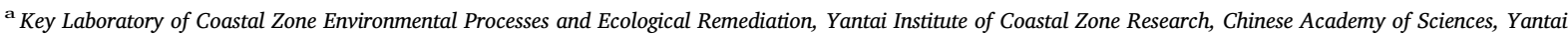 \\ 264003, China \\ ${ }^{\mathbf{b}}$ University of Chinese Academy of Sciences, Beijing 100049, China \\ ${ }^{\mathrm{c}}$ Shandong Marine Resources and Environment Research Institute, Yantai 264006, China \\ d State Key Laboratory of Estuarine and Coastal Research, East China Normal University, Shanghai 200062, China
}

A R T I C L E I N F O

\section{Keywords:}

Eutrophication

Harmful algal blooms

Nitrogen reduction

Yellow River

Xiaoqing River

\begin{abstract}
A B S T R A C T
The response of phytoplankton assemblages to decreases in nitrogen loading is an essential index to assess the recovery of aquatic ecosystems from eutrophic status. However, a positive signal is hard to observe from shortterm operations considering ecosystem complexity. Here, we used decadal data from the Laizhou Bay, China to track the seasonal and annual variations in phytoplankton assemblages after ammonia reduction in the Xiaoqing and Yellow Rivers. Annual trends show reduced phytoplankton abundance and a decline in harmful algal blooms, indicating the positive recovery of phytoplankton assemblages. Phytoplankton assemblage in the sea region adjacent to the Xiaoqing River shows a lower $H^{\prime}$ index, higher cell abundance, and higher seasonal variability than the sea region neighbouring the Yellow River. The spatial variability might result from the differences of nitrogen species, runoff and sediment contents between the two rivers; this finding indicates a demand for more aggressive decreases in nitrogen loads.
\end{abstract}

\section{Introduction}

Phytoplankton is an important component in regulating element recycling and energy flow in the ocean (Field et al., 1998). Over several recent decades, phytoplankton regime shifts have been observed in many coastal systems, with a trend shifting from diatom dominance to proportionately more flagellates and cyanobacteria, many of which are harmful algal bloom (HAB) species (Anderson et al., 2002; Taylor et al., 2002; Glibert and Burford, 2017). Moreover, increased phytoplankton biomasses have enlarged the magnitudes of coastal hypoxia, which consequently threaten fishery sustainability (Cloern, 2001; Diaz and Rosenberg, 2008; Paerl et al., 2014). Nutrient enrichment and the resulting alteration in the balance and stoichiometry of different nutrients is one of the most important and recognized mechanisms to explain phytoplankton regime shift in many coastal waters (Smayda, 1990; Anderson et al., 2002; Conley et al., 2009; Glibert and Burford, 2017). In contrast to increases in dissolved inorganic nitrogen (DIN) and dissolved inorganic phosphate $\left(\mathrm{PO}_{4}-\mathrm{P}\right)$, there is evidence for decreasing dissolved silica $\left(\mathrm{SiO}_{3}-\mathrm{Si}\right)$ concentrations in coastal waters, largely due to sediment trapping and elemental transformations following construction of dams (Vörösmarty et al., 2003; Beusen et al., 2009). Such asymmetric changes between $\mathrm{DIN}, \mathrm{PO}_{4}-\mathrm{P}$, and $\mathrm{SiO}_{3}-\mathrm{Si}$ have resulted in a gradual move from $\mathrm{N}$ to $\mathrm{P}$ or $\mathrm{Si}$ limitation in many coastal systems (Conley and Malone, 1992; Ragueneau et al., 1994), and long-term increases in N/P and N/Si ratios have been associated with compositional shifts in phytoplankton assemblages and HABs (Anderson et al., 2002; Glibert and Burford, 2017).

Laizhou Bay in the Bohai Sea, China is a eutrophic coastal embayment of this type. There were 5- to 15-fold increases in DIN between the 1980 s and the 2000s in the Laizhou Bay due to the rapid development of industrial and agricultural activities along the coastline (Jiang et al., 2005). In contrast to the increase in DIN, there has been a decrease in $\mathrm{SiO}_{3}-\mathrm{Si}$ and $\mathrm{PO}_{4}-\mathrm{P}$ availability, largely due to sediment trapping and elemental transformations associated with the construction of dams, and the government policy for phosphorus usage control (Jiang et al., 2018). The asymmetrical changes among elements have skewed N/P ratios, which increase to $50-1000$ in spring and summer and greatly exceed Redfield Ratio; meanwhile, $\mathrm{Si} / \mathrm{N}$ ratios decreased to $<0.5$

\footnotetext{
* Corresponding author at: State Key Laboratory of Estuarine and Coastal Research, East China Normal University, Zhongshan N. Road 3663, Shanghai 200062, China.

E-mail address: dyliu@sklec.ecnu.edu.cn (D. Liu).
} 


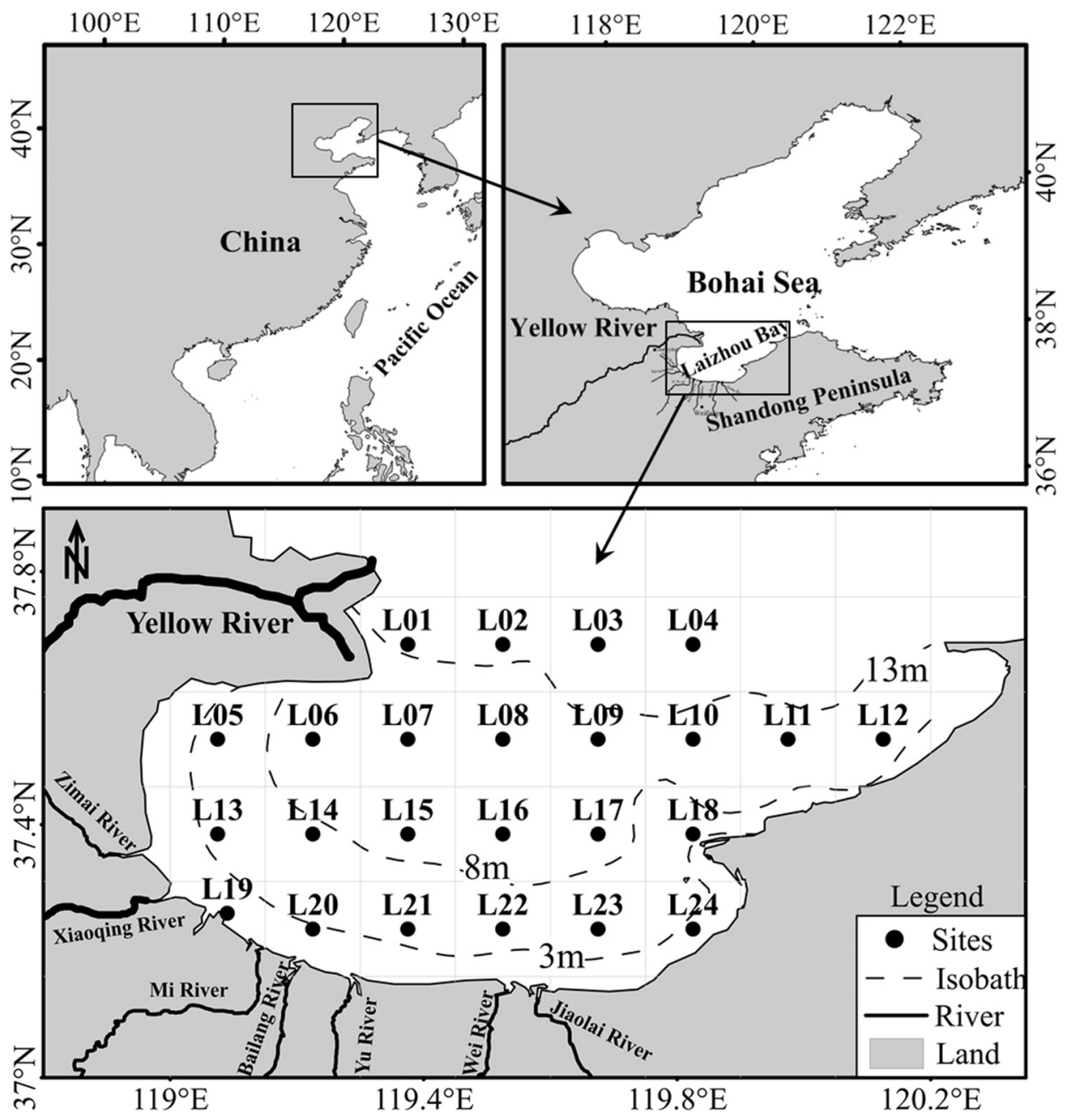

Fig. 1. Map of Laizhou Bay showing sampling stations and isobaths.

(Jiang et al., 2005). As a consequence of this eutrophication, Laizhou Bay now routinely experiences HAB occurrences, often involving toxic non-diatom species (e.g., Chattonella marina) (Zhang et al., 2005; Yang et al., 2006; Yu et al., 2012). Laizhou Bay is an important spawning and nursery ground and supports the fishery in the Bohai Sea, China, and thus, the decreased water quality and increased HABs have had a distinct impact on the fishery economy (Tang et al., 2003; Jin et al., 2013).

Reducing the amount of nitrogen in the system, with the aim of lowering the frequency of HABs and reducing the phytoplankton biomass, is one of the effective ways for the ecological restoration of eutrophic systems. For example, HABs in the Seto Inland Sea, Japan have decreased by $30 \%$ since 1977 after the reduction of chemical oxygen demand and nitrogen loadings (Anderson et al., 2002). Reducing the sewage discharge into Victoria Harbour, Hong Kong also lowered HABs and increased diatom proportions (Lam and Ho, 1989; Yung et al., 1997). Therefore, the Shandong provincial government launched a policy on prevention and control of river pollution around the Laizhou Bay since 2000, aiming to improve the water quality and reduce HABs. Until 2014, the average ammonia concentration in approximately 50 rivers located in Shandong province continuously decreased for 12 consecutive years, and ammonia loadings from the two major rivers (Xiaoqing River and Yellow River) entering into the Laizhou Bay decreased 86.4\% and 57.5\% (Ma et al., 2004; Environmental Bulletin of Shandong Province, 2004-2015), respectively. Consequently, DIN in the bay correspondingly decreased by approximately $10-30 \%$ compared with the levels in 2004 (Jiang et al., 2018). It is important to further examine whether and how the phytoplankton assemblages are responding to the DIN decrease in the Laizhou Bay, and this will help us better understand the effects of nutrient control on the ecological restoration in eutrophic coasts. Here, we tracked the seasonal and annual variations of phytoplankton assemblages in the Laizhou Bay, using a set of decadal data collected during 2004-2014. The effects of reduced ammonia concentrations were assessed according to the changes in species diversity, cell abundance and frequency of HABs in the bay. The spatial difference between sea regions resulting from runoff of the Xiaoqing and Yellow Rivers are discussed, in combination with other environmental parameters.

\section{Materials and methods}

\subsection{Sampling sites}

Laizhou Bay is located in the southern Bohai Sea, China, with an area of approximately $7000 \mathrm{~km}^{2}$ and an average water depth of $9 \mathrm{~m}$; it receives freshwater and nutrient inputs from $>10$ continental rivers around the catchment, including two large rivers, the Xiaoqing River and Yellow River (Fig. 1). The shallow topography and large amount of river inputs generate water quality with low salinity and high nutrients. In general, a northwestern coastal current flows into the bay and forms an anti-clockwise circulation, which is mainly responsible for water exchange, combining with tidal action. In summer, increased Yellow River runoff can produce one eastward plume at the river mouth and impacts the adjacent sea (Liu, 2015).

During 2004-2014, the ecological cruises in the Laizhou Bay, with a 

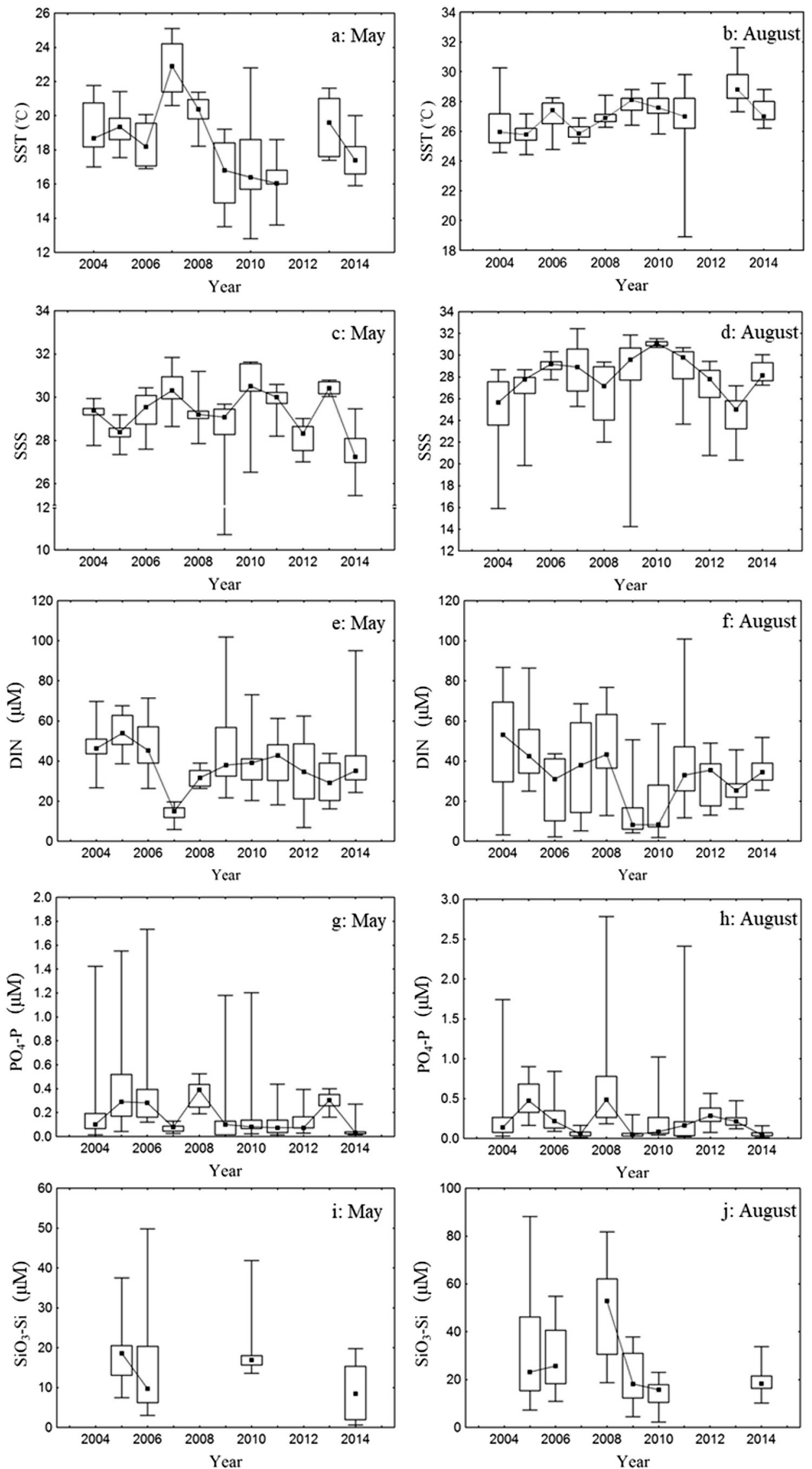

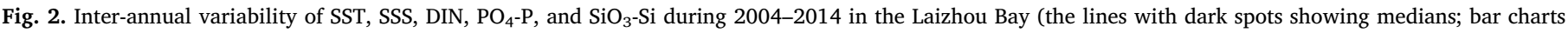
showing the interquartile ranges). 

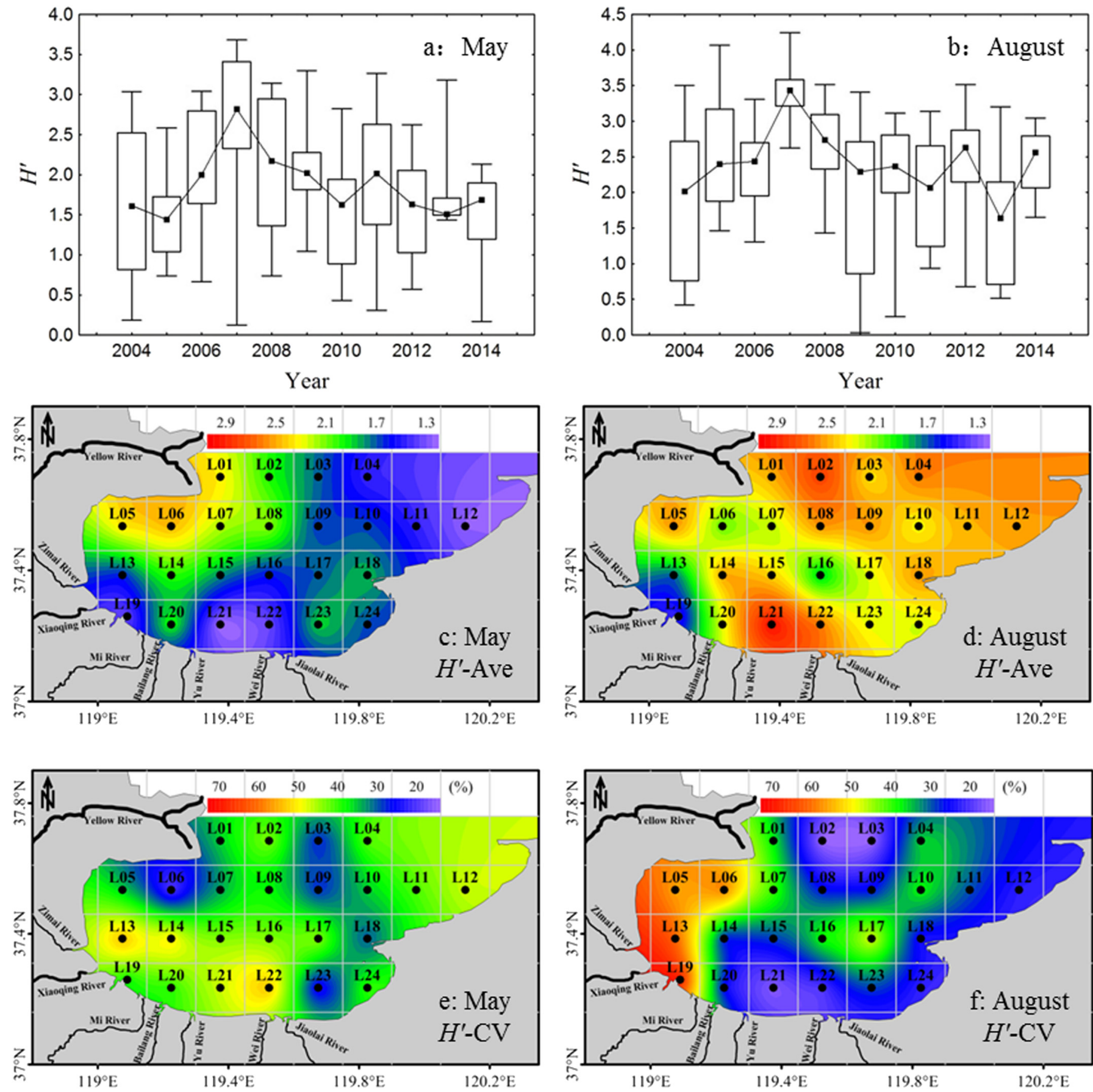

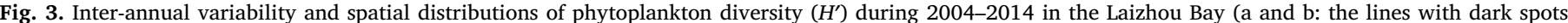

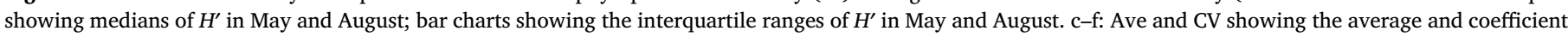
of variation of $H^{\prime}$ in May and August, respectively).

purpose of monitoring variations in environmental factors, phytoplankton assemblages and HABs, were carried out at 24 stations and twice of each year (May and August), representing spring and summer, respectively (Fig. 1). The environmental factors including surface sea temperature (SST), surface sea salinity (SSS), and nutrients (DIN, $\mathrm{PO}_{4}-\mathrm{P}$, $\mathrm{SiO}_{3}$-Si) were examined. SST and SSS are measured in situ using YSI Professional Plus handheld multiparameter meter (YSI Inc., Yellow Springs, OH, USA). One liter surface seawater samples were collected and filtered in situ using GF/F filters under low vacuum. The filtered seawater samples were preserved using trichloromethane $(0.2 \%$ final concentration) and frozen for nutrient analysis. Phytoplankton samples were collected vertically using a phytoplankton net $(0.37 \mathrm{~m}$ mouth diameter, $76 \mu \mathrm{m}$ mesh) from the bay bottom to the surface. The collected phytoplankton samples were fixed with Lugol's iodine solution (1\% final concentration) and transported to the laboratory for species identification and cell enumeration.

\subsection{Analysis of environmental factors}

Nutrients are analysed according to the Specification for Oceanographic Survey of China (GB 12763.4-2007) after thawing the samples at $4{ }^{\circ} \mathrm{C} . \quad \mathrm{NO}_{2}-\mathrm{N}$ was measured using the $\mathrm{N}$-(1-naphthyl)-ethylenediamine dihydrochloride spectrophotometric method. $\mathrm{NO}_{3}-\mathrm{N}$ was reduced to $\mathrm{NO}_{2}-\mathrm{N}$ by cadmium-zinc column and 

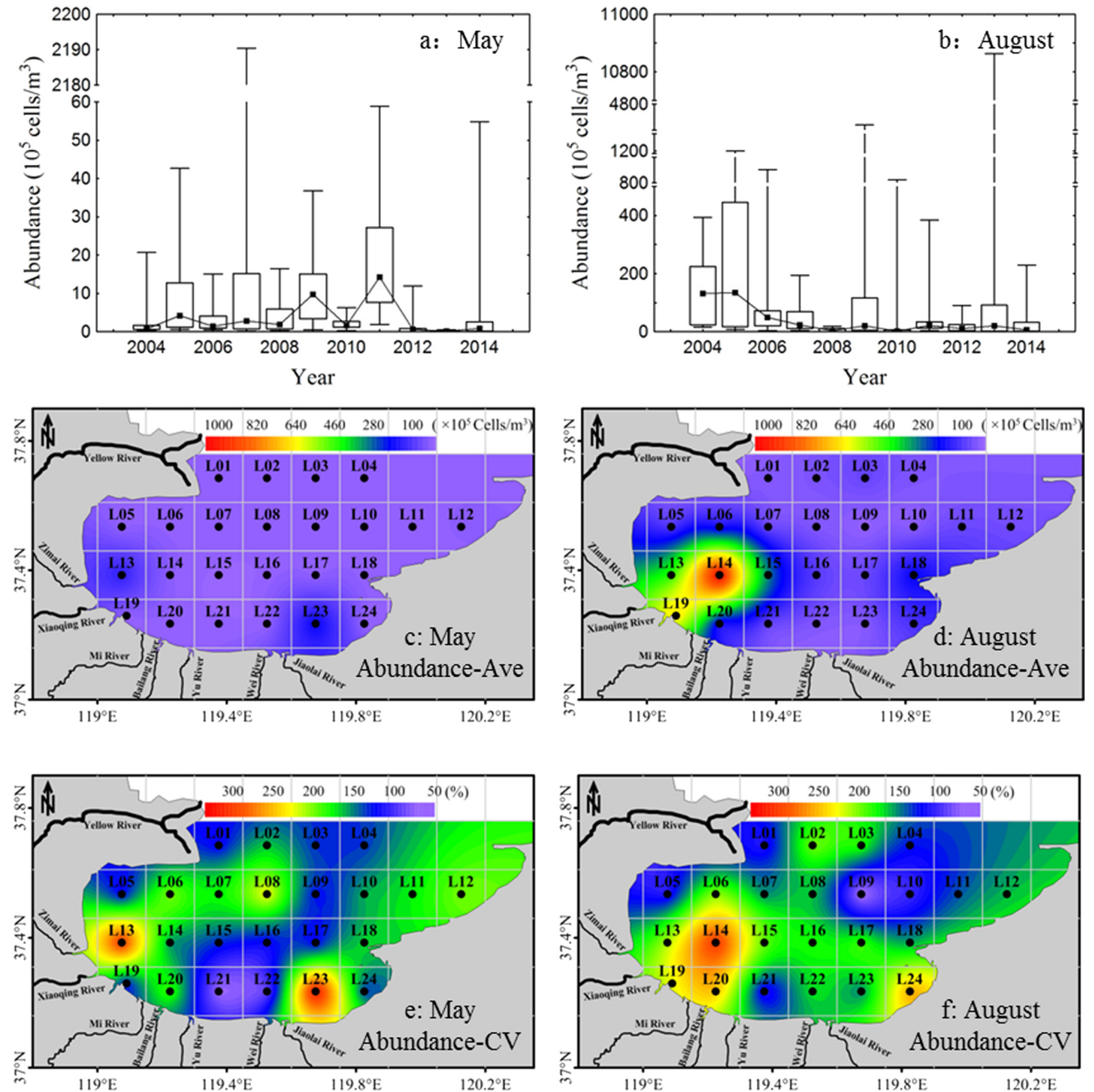

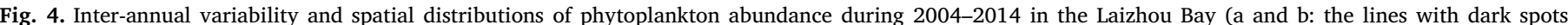

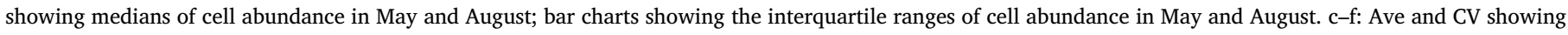
the average and coefficient of variation of cell abundance in May and August, respectively).

then measured using the $N$-(1-naphthyl)-ethylenediamine dihydrochloride spectrophotometric method. $\mathrm{NH}_{4}-\mathrm{N}$ was oxidized to $\mathrm{NO}_{2}-\mathrm{N}$ by hypobromite and then measured using the $N$-(1-naphthyl)-ethylenediamine dihydrochloride spectrophotometric method. DIN is the sum of $\mathrm{NO}_{2}-\mathrm{N}, \mathrm{NO}_{3}-\mathrm{N}$ and $\mathrm{NH}_{4}-\mathrm{N}$. $\mathrm{PO}_{4}-\mathrm{P}$ was measured using the phosphor-molybdenum blue spectrophotometric method. $\mathrm{SiO}_{3}$-Si was measured by the silico-molybdenum blue method. The detection limits were $0.02 \mu \mathrm{M}$ for $\mathrm{NO}_{2}-\mathrm{N}, 0.05 \mu \mathrm{M}$ for $\mathrm{NO}_{3}-\mathrm{N}$, $0.03 \mu \mathrm{M}$ for $\mathrm{NH}_{4}-\mathrm{N}, 0.02 \mu \mathrm{M}$ for $\mathrm{PO}_{4}-\mathrm{P}$ and $0.1 \mu \mathrm{M}$ for $\mathrm{SiO}_{3}-\mathrm{Si}$.

The variations of environmental factors (SST, SSS and nutrients) were published in Jiang et al. (2018). Here, we showed the trends of environmental factors during 2004-2014 to help understanding the response of phytoplankton assemblages to environmental changes (Fig. 2). In general, SST shows a median range of $16.1-22.9^{\circ} \mathrm{C}$ in May and $25.8-28.8^{\circ} \mathrm{C}$ in August; and high temperature occurred in May of 2007 and August of 2013 (Fig. 2a, b). Due to the impact of wet season, SSS is lower in August (average: 27.7) than May (average: 29.1) (Fig. 2c, d). DIN concentrations present a median range of 15.1-54.0 $\mu \mathrm{M}$ in May and of 8.14-53.1 $\mu \mathrm{M}$ in August, respectively, showing a significantly decreasing annual trend (Fig. 2e, f). The median variation in $\mathrm{PO}_{4}-\mathrm{P}$ concentrations are $0.03-0.39 \mu \mathrm{M}$ in May and $0.04-0.49 \mu \mathrm{M}$ in August, respectively, indicating a very slight decline 


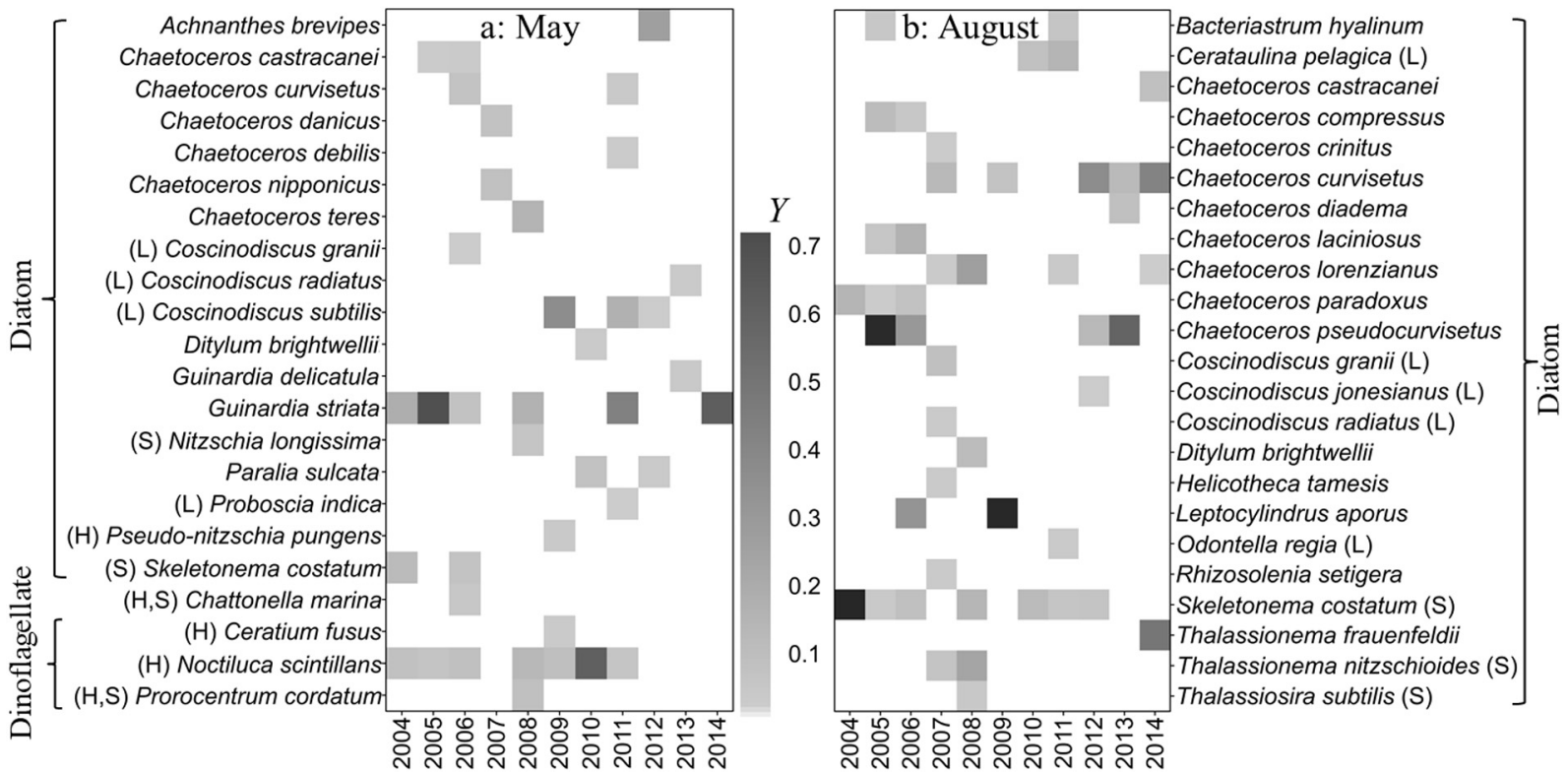

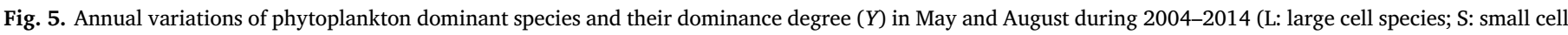
species; H: HAB species).

(Fig. 2g, h). $\mathrm{SiO}_{3}-\mathrm{Si}$ concentrations present a decreasing trend with average concentration of $15.3 \mu \mathrm{M}$ in May and $27.7 \mu \mathrm{M}$ in August; and higher $\mathrm{SiO}_{3}-\mathrm{Si}$ in August indicates the impact of river input during the wet season (Fig. 2i, j). Notably, the spatial variations of SSS and nutrients are more distinct than SST, due to the impact of river inputs, particularly in August (Fig. 2).

\subsection{Phytoplankton analysis}

Phytoplankton taxa were identified to species or genus level under $200 \times$ or $400 \times$ magnification with a light microscope (Leica DM 2500), and the cells were enumerated using Kolkwitz counting chamber $(0.5 \mathrm{~mL})$. Community diversity was calculated using the ShannonWiener diversity index $\left(H^{\prime}\right)$.

$H^{\prime}=-\sum_{i=1}^{S} P_{i} \log _{2} P_{i}$

where $P_{i}$ is the proportion of individuals in a sample unit belonging to species $i, S$ is the number of species identified in the sample.

The importance of dominant species was evaluated using dominance degree $(Y)$ data matched, which is calculated as:

$Y=\left(n_{i} / N\right) \times f_{\mathrm{i}}$

where $n_{i}$ is the individual number of the species $i, N$ is the total number of individuals in the sample, and $f_{i}$ is the occurrence frequency of species $i$ among the stations of each cruise. The species with $Y>0.02$ were identified for the analysis of dominant species.

\subsection{Statistical analysis}

Coefficient of variation (CV) and interquartile range were calculated using the software of STATISTICA 6.0, with the aim of mapping the spatial and temporal variability of phytoplankton abundance and $H^{\prime}$ index in the Laizhou Bay. The redundancy analysis (RDA) between dominant species and environmental variables (SST, SSS, DIN, $\mathrm{NO}_{2}-\mathrm{N}$, $\mathrm{NO}_{3}-\mathrm{N}, \mathrm{NH}_{4}-\mathrm{N}, \mathrm{PO}_{4}-\mathrm{P}, \mathrm{SiO}_{3}-\mathrm{Si}, \mathrm{N} / \mathrm{P}$ ratio, $\mathrm{Si} / \mathrm{N}$ ratio, and $\mathrm{Si} / \mathrm{P}$ ratio) was analysed using the statistical program CANOCO Version 4.5 (Lepš and Šmilauer, 2003) to examine the phytoplankton response to changed environmental conditions. The environmental data (Fig. 2) matched to phytoplankton surveys are used for RDA analysis.

\section{Results}

\subsection{Phytoplankton diversity $\left(H^{\prime}\right)$}

In total, 179 different taxa are identified, including 145 diatom species and 34 dinoflagellate species. In general, the annual trend of the $H^{\prime}$ index displays significant inter-annual variation, with a maximum in 2007 (average: 2.8 in May and 3.4 in August) (Fig. 3a, b). An 11-year averaged $H^{\prime}$ index shows that species diversity is higher in August than May, with a significant spatial difference (Fig. 3c-d). Higher $H^{\prime}$ index values $(>2)$ occur in the sea region near the Yellow River and mouth of the bay with lower annual variability; and this is more significant in August (Fig. 3c-f). In contrast, the sea region near the Xiaoqing River is characterized by a lower $H^{\prime}$ index $(<2)$ and higher variability (Fig. 3c-f).

\subsection{Phytoplankton abundance}

The annual trends of cell abundance in May and August show different patterns (Fig. 4a, b). In May, the annual variation of averaged cell abundance had a range of $0.1 \times 10^{5}-14.2 \times 10^{5}$ cells.m $^{-3}$ and displays a variable pattern (Fig. 4a). In comparison, cell abundance in August is much higher than in May, with a range of $2.2 \times 10^{5}-134.4 \times 10^{5} \mathrm{cells}^{-3} \mathrm{~m}^{-3}$; and cell abundance shows a significant deceasing annual trend corresponding to decreases in ammonia concentrations (Fig. 4b). Cell abundance in the sea region near the Xiaoqing River in May show much lower values than in August; in contrast, cell abundance near the Yellow River shows little difference between May and August (Fig. 4c-d). The spatial variability of cell abundance (CV) at the sea region near Xiaoqing River both in May and August displays high variability, while in contrast, the CV near the Yellow River is relatively lower (Fig. 4e, f).

\subsection{Dominant species shift}

Dominant species and their degree of dominance $(Y)$ display significant differences in annual and seasonal scales (Fig. 5). Dominant species in May are shared by diatoms and dinoflagellates (Ceratium fusus, Noctiluca scintillans, Prorocentrum cordatum, and Chattonella marina) in most years, but there was no dinoflagellate dominance in 

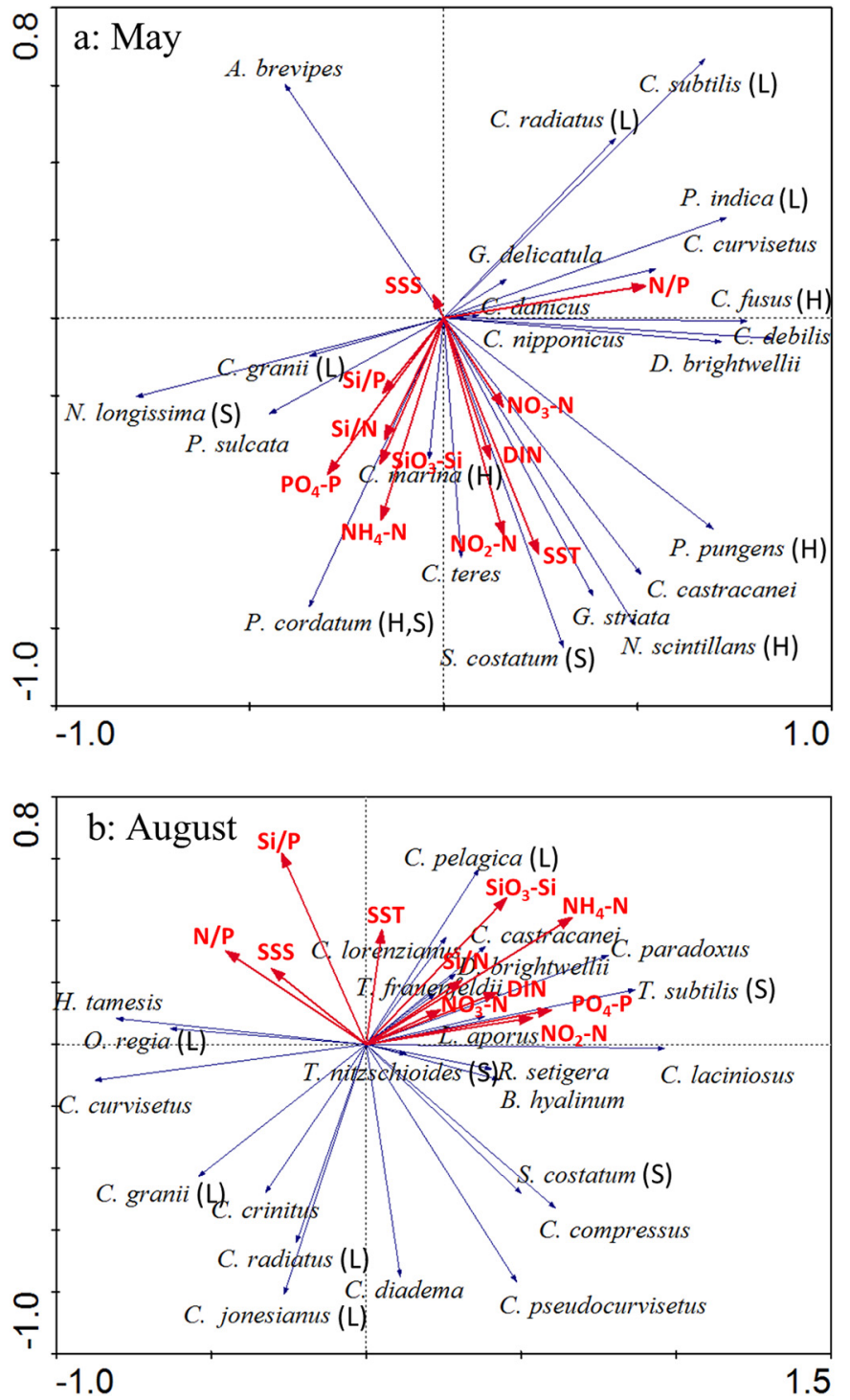

Fig. 6. RDA analysis in dominant phytoplankton species and environmental factors (L: large cell species; S: small cell species; H: HAB species).

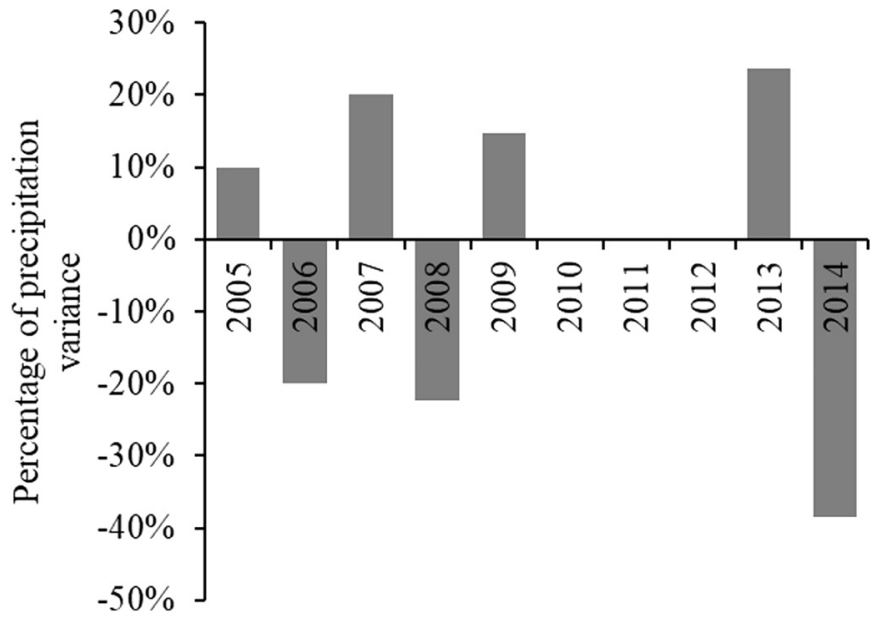

Fig. 7. Percentage of annual precipitation to multi-year averaged precipitation in Dongying during 2005-2014 (Dongying is the nearest city to Xiaoqing and Yellow Rivers; Rain data from Shandong Province Water Resources Bulletin: http://www.sdwr.gov.cn).
2007 and during 2012-2014 (Fig. 5a). In contrast, the dominant species in August are all diatoms (Fig. 5b). The dominant degree of large diatom (Cerataulina pelagica, Coscinodiscus jonesianus, Odontella regia) increased while small diatom Skeletonema costatum decreased in the annual trend (Fig. 5).

The correlations between dominant assemblages and environmental variables were analysed using RDA (Fig. 6). The four axes explain $78.4 \%$ and $78.9 \%$ of species-environment relationships in May and August, respectively. The importance of environmental factors impacting the dominant assemblages show a trend with $\mathrm{SST}>\mathrm{NO}_{2}$ $\mathrm{N}>\mathrm{NH}_{4}-\mathrm{N}>\mathrm{N} / \mathrm{P}>\mathrm{PO}_{4}-\mathrm{P}>\mathrm{SiO}_{3}-\mathrm{Si}>\mathrm{DIN}>\mathrm{Si} / \mathrm{N}>\mathrm{NO}_{3^{-}}$ $\mathrm{N}>\mathrm{Si} / \mathrm{P}>\mathrm{SSS}$ in May, and $\mathrm{NH}_{4}-\mathrm{N}>\mathrm{Si} / \mathrm{P}>\mathrm{SiO}_{3}-\mathrm{Si}>\mathrm{PO}_{4^{-}}$ $\mathrm{P}>\mathrm{N} / \mathrm{P}>\mathrm{NO}_{2}-\mathrm{N}>\mathrm{DIN}>\mathrm{SSS}>\mathrm{SST}>\mathrm{Si} / \mathrm{N}>\mathrm{NO}_{3}-\mathrm{N}$ in August. This result indicates that SST is more important than nitrogen in May, but the importance of ammonia increases in August, and significantly increased rainfall and runoff might promote the importance of nutrients in August. Generally, large species, such as Coscinodiscus granii, $C$. jonesianus, $C$. radiatus, $C$. subtilis, Probosica indica, and $O$. regia, show negative correlation with nutrient concentrations, while small species, such as $S$. costatum, Nitzschia longissima, $P$. cordatum and Thalassiosira subtilis, show positive correlations with nutrient concentrations (Fig. 6).

\section{Discussion}

Nitrogen enrichment leading to significant impacts on the phytoplankton assemblage, e.g., decreasing species diversity, diminishing cell size, increasing cell abundance, and causing HABs, has been well studied and understood (Anderson et al., 2002; Spatharis et al., 2007; Wyatt, 2013; Paerl et al., 2014; Glibert, 2017). In contrast, our knowledge on phytoplankton recovery following nutrient reduction is limited. Existing studies indicate that it is hard to return a eutrophic system to a previous baseline using only nutrient control, because ecosystem shift is a process with the interaction of multiple pressures (Taylor et al., 2011; Duarte et al., 2015). Some aquatic ecosystems have demonstrated that partial recovery from nutrient control can be attainable on a decadal scale, e.g., reduced phytoplankton biomass and decline in HABs (Yung et al., 1997; Zhu et al., 2015; Riemann et al., 2016). Of reduced ammonia content in the Xiaoqing and Yellow Rivers showed an effect on the DIN levels in the Laizhou Bay (Sun et al., 2017; Jiang et al., 2018) and reduced phytoplankton abundance on a decadal scale, but they displayed significant spatial differences and annual variability. Here, we discuss the different responses of the phytoplankton assemblages for the sea regions near the Xiaoqing and Yellow Rivers after a reduction in ammonia concentrations, correlated to environmental factors.

The sea area near the Xiaoqing River is the most polluted region in the Laizhou Bay (Ma et al., 2004; Jiang et al., 2018). This is attributed to high nitrogen loading, e.g., the annual flux showed a range of $30.86 \times 10^{3}-43.87 \times 10^{3}$ t during 2008-2013 (Jiang et al., 2017) and to slow water exchange rates in the inner bay. Ammonia is the dominant $\mathrm{N}$ component in the Xiaoqing River which is mainly from sewage discharge and animal aquaculture, and it contributes $>90 \%$ of the nitrogen loading (Ma et al., 2004). The annual and seasonal variability of river runoff can significantly impact the amount of nitrogen loading to the bay (Jiang et al., 2017). The monitoring data during 1998-2013 showed that nitrogen loading reached peak values during the wet season (from July to September), particularly in August (Ma et al., 2004; Jiang et al., 2017). The climatic records in Dongying (the nearest city to Xiaoqing and Yellow Rivers) indicate positive correlation between precipitation and cell abundance (Fig. 7). For example, wet years (2005, 2007, 2009, and 2013) generally corresponded to high cell abundance while the low cell abundance appeared in dry years (2008 and 2014). High CV at the sea region near the Xiaoqing River (Fig. $4 \mathrm{f}$ ) and the result of RDA (Fig. 6) in August (wet season) indicate the importance of river runoff. 


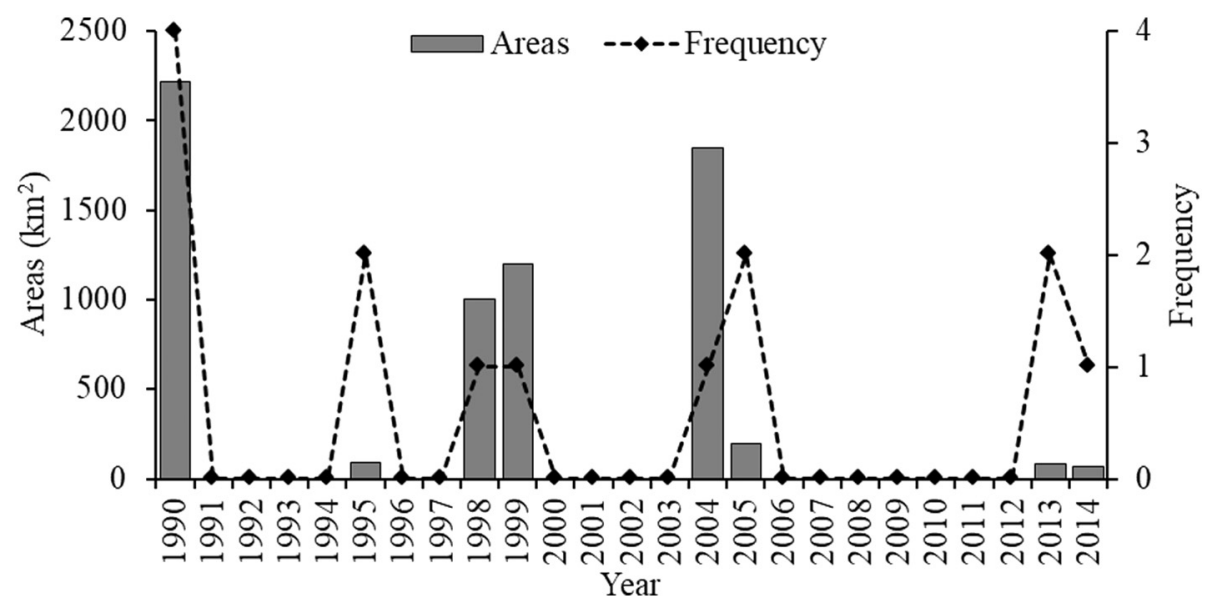

Fig. 8. Frequency and blooming areas of HABs recorded in the Laizhou Bay during 1990-2014.

(Data from Zhang et al. (2005), Yang et al. (2006), and our laboratory observations.)

The impact of river runoff, however, is not reflected in the sea region near the Yellow River, although the annual runoff and nitrogen loading $\left(50.1 \times 10^{3}-91 \times 10^{3} \mathrm{t}\right)$ in the Yellow River is much higher than in the Xiaoqing River (Ma et al., 2004; Liao et al., 2013). This might be related to the nitrogen species and sediment contents in the Yellow River. Nitrate is the dominant N component in the Yellow River and contributes $>90 \%$ of the DIN loading (Ma et al., 2004; Liao et al., 2013), and thus reduction in ammonia content in the Yellow River cannot deplete nitrogen loading as much as in the Xiaoqing River. Moreover, the sediment discharge from the Yellow River contributes $6 \%$ of the estimated global river sediment flux to the ocean (Milliman and Meade, 1983). This generates high turbidity water in the sea region near the Yellow River which can distinctly decrease light availability and restrain the growth of phytoplankton (May et al., 2003; Wang et al., 2017). Thus, the cell abundance and CV in the sea region near the Yellow River is much lower than around the Xiaoqing River (Fig. 4c, d).

Nitrogen loading from the Yellow River to the bay is impacted by precipitation and Water-Sediment Regulation Scheme (WSRS). WSRS started in 2002, with the aim of regulating water flow and reducing sediment deposition in the lower reaches of the river by the controlled release of large amounts of water over a short period (Bi et al., 2014). The WSRS activity during June-July brings abundant sediment, approximately $26-66 \%$ of the annual sediment load, into the Laizhou Bay (Wang et al., 2017). Therefore, the WSRS event generates very high suspended sediment concentrations in the sea region near the Yellow River and limits the light intensity for growth of phytoplankton. However, it brings substantial silicate into the bay and supports the diatom dominance in August (Figs. 2j, 5b).

Nitrogen enrichment could decrease the phytoplankton species diversity, increase $\mathrm{HAB}$ species, and diminish cell size (Anderson et al., 2002). In this study, $H^{\prime}$ values are variable, high $H^{\prime}$ values occur in the sea region near the Yellow River (Fig. 3). River runoff not only brings rich nutrients to the bay but also reduces seawater salinity (Fig. 2c, d), and these changes can widen niches of phytoplankton species and increase species diversity (Huston, 1979; Sommer et al., 1993). However, this does not appear at the sea region near the Xiaoqing River, where $H^{\prime}$ is low $(<2)$ and $\mathrm{CV}$ is high $(>50 \%)$. Although we cannot fully explain the reason, high $\mathrm{CV}$ in cell abundance and $H^{\prime}$ indicated the distinct impact of inter-annual variation in runoff. Previous surveys of the sea region near the Xiaoqing River also examined high nutrients in wet years or seasons (Jiang et al., 2017; Sun et al., 2017; Jiang et al., 2018). These indicate that we may not give enough attention to the variations of runoff impact on annual and seasonal scales.

Increased frequency and intensity of HABs are often accompanied with increased nutrient loading. In this study, the dominant opportunist $\mathrm{HAB}$ species in May, including Noctiluca scintillans, Prorocentrum cordatum, Chattonella marina, Pseudo-nitzschia pungens and Ceratium fusus, display decreasing trends (Fig. 5). Compared with the historical records of HABs, the frequency and areas of HABs in the Laizhou Bay significantly declined over the last decade (Fig. 8) and large diatoms increased (Fig. 5). These signals indicate the positive response of phytoplankton assemblages to reduction in ammonia inputs.

In summary, the policy of reducing ammonia inputs to the Xiaoqing and Yellow Rivers shows a positive effect on the recovery of phytoplankton assemblages in the Laizhou Bay over the last decade. The spatial difference of phytoplankton assemblages corresponding to the Xiaoqing and Yellow Rivers indicate, however, that the program of ammonia reduction needs an improvement, e.g., nitrate inputs reduction in the Yellow River could be more important than ammonia inputs reduction. It might be necessary to consider more aggressive actions in the rainy season and in wet years.

\section{Acknowledgements}

We appreciate the support of colleagues working on the cruises in the Laizhou Bay during 2004-2014. The research was funded by the Natural Science Foundation of China, China (41776126, 41876127), Joint Funds of Natural Science Foundation of China and Shandong Province, China (U1706219), and Ministry of Science and Technology, China (2016YFA0600904).

\section{References}

Anderson, D.M., Glibert, P.M., Burkholder, J.M., Rabalais, N.N., Nixon, S.W., 2002. Harmful algal blooms and eutrophication: nutrient sources, composition, and consequences. Estuaries 25, 704-726.

Beusen, A.H.W., Bouwman, A.F., Dürr, H.H., Dekkers, A.L.M., Hartmann, J., 2009. Global patterns of dissolved silica export to the coastal zone: results from a spatially explicit global model. Glob. Biogeochem. Cycles 23, GB0A02.

Bi, N., Yang, Z.S., Wang, H.J., Xu, C.L., Guo, Z.G., 2014. Impact of artificial water and sediment discharge regulation in the Huanghe (Yellow River) on the transport of particulate heavy metals to the sea. Catena $121,232-240$.

Cloern, J.E., 2001. Our evolving conceptual model of the coastal eutrophication problem. Mar. Ecol. Prog. Ser. 210, 223-253.

Conley, D.J., Malone, T.C., 1992. Annual cycle of dissolved silicate in Chesapeake bay: implications for the production and fate of phytoplankton biomass. Mar. Ecol. Prog. Ser. 81, 121-128.

Conley, D.J., Paerl, H.W., Howarth, R.W., Boesch, D.F., Seitzinger, S.P., Havens, K.E., Lancelot, C., Likens, G.E., 2009. Controlling eutrophication: nitrogen and phosphorus. Science 323, 1014-1015.

Diaz, R.J., Rosenberg, R., 2008. Spreading dead zones and consequences for marine ecosystems. Science 321, 926-929.

Duarte, C.M., Borja, A., Carstensen, J., Elliott, M., Krause-Jensen, D., Marbà, N., 2015 Paradigms in the recovery of estuarine and coastal ecosystems. Estuar. Coasts 38, 1202-1212.

Field, C.B., Behrenfeld, M.J., Randerson, J.T., Falkowski, P., 1998. Primary production of the biosphere: integrating terrestrial and oceanic components. Science 281, 237-240. 
Glibert, P.M., 2017. Eutrophication, harmful algae and biodiversity - challenging paradigms in a world of complex nutrient changes. Mar. Pollut. Bull. 124, 591-606.

Glibert, P.M., Burford, M.A., 2017. Globally changing nutrient loads and harmful algal blooms: recent advances, new paradigms, and continuing challenges. Oceanography 30, 58-69.

Environmental Bulletin of Shandong Province, 2004-2015. http://xxgk.sdein.gov.cn/ xxgkml/hjzkgb/ (issued by Environment Protection Administration of Shandong Province).

Huston, M., 1979. A general hypothesis of species diversity. Am. Nat. 113, 81-101.

Jiang, H., Cui, Y., Chen, B.J., Chen, J.F., Song, Y.L., 2005. The variation trend of nutrient salts in the Bohai Sea. Mar. Fish. Res. 26, 61-67 (in Chinese, with English abstracts).

Jiang, D.J., Wang, Q., Li, R.Z., Zhang, H., 2017. Simulation of total nitrogen transport based on swat model in Xiaoqing river basin of Shandong province. J. Water Resour. Water Eng. 28, 1-7 (in Chinese, with English abstracts).

Jiang, H.C., Wang, Y.J., Li, J.H., Tao, H.M., Bai, Y.Y., Su, B., Liu, D.Y., 2018. Annual variation and spatial distribution of nutrients in Laizhou Bay. Mar. Sci. Bull. 37, 411-423 (in Chinese, with English abstracts).

Jin, X.S., Shan, X.J., Li, X.S., Wang, J., Cui, Y., Zuo, T., 2013. Long-term changes in the fishery ecosystem structure of Laizhou Bay, China. Sci. China Earth Sci. 56, 366-374.

Lam, C.W.Y., Ho, K.C., 1989. Red tides in Tolo Harbour, Hong Kong. In: Okaichi, T., Anderson, D.M., Nemoto, T. (Eds.), Red Tides: Biology, Environmental Science and Toxicology. Elsevier, New York, pp. 49-52.

Lepš, J., Šmilauer, P., 2003. Multivariate Analysis of Ecological Data Using CANOCO. Cambridge University Press, Cambridge.

Liao, W., Zhang, L.J., Chen, H.T., Xiao, C.C., Zhang, X., 2013. Nutrients variations and fluxes estimation in the yellow river estuary from 2001 to 2011. Period. Ocean Univ. China 43, 81-86 (in Chinese, with English abstracts).

Liu, S.M., 2015. Response of nutrient transports to water-sediment regulation events in the Huanghe basin and its impact on the biogeochemistry of the Bohai. J. Mar. Syst. 141, 59-70.

Ma, S.S., Xin, F.Y., Cui, Y., Qiao, X.Y., 2004. Assessment of main pollution matter volume into the sea from Yellow River and Xiaoqing River. Mar. Fish. Res. 25, 47-51 (in Chinese, with English abstracts).

May, C.L., Koseff, J.R., Lucas, L.V., Cloern, J.E., Schoellhamer, D.H., 2003. Effects of spatial and temporal variability of turbidity on phytoplankton blooms. Mar. Ecol. Prog. Ser. 254, 111-128.

Milliman, J.D., Meade, R.H., 1983. World-wide delivery of river sediment to the oceans. J. Geol. 91, 1-21.

Paerl, H.W., Hall, N.S., Peierls, B.L., Rossignol, K.L., 2014. Evolving paradigms and challenges in estuarine and coastal eutrophication dynamics in a culturally and climatically stressed world. Estuar. Coasts 37, 243-258.

Ragueneau, O., Varela, E.D.B., Tréguer, P., Quéguiner, B., Amo, Y.D., 1994. Phytoplankton dynamics in relation to biogeochemical cycle of silicon in a coastal ecosystem of Western Europe. Mar. Ecol. Prog. 106, 157-172.

Riemann, B., Carstensen, J., Dahl, K., Fossing, H., Hansen, J.W., Jakobsen, H.H., Josefson, A.B., Krause-Jensen, D., Markager, S., Stæhr, P.A., Timmermann, K., Windolf, J.,
Andersen, J.H., 2016. Recovery of Danish coastal ecosystems after reductions in nutrient loading: a holistic ecosystem approach. Estuar. Coasts 39, 82-97.

Smayda, T.J., 1990. Novel and nuisance phytoplankton blooms in the sea: evidence for a global epidemic. In: Granéli, E., Sundström, B., Edler, L., Anderson, D.M. (Eds.), Toxic Marine Phytoplankton. Elsevier, NY, pp. 29-40.

Sommer, U., Padisák, J., Reynolds, C.S., Juhász-Nagy, P., 1993. Hutchinson's heritage: the diversity-disturbance relationship in phytoplankton. Hydrobiologia 249, 1-7.

Spatharis, S., Tsirtsis, G., Danielidis, D.B., Chi, T.D., Mouillot, D., 2007. Effects of pulsed nutrient inputs on phytoplankton assemblage structure and blooms in an enclosed coastal area. Estuar. Coast. Shelf Sci. 73, 807-815.

Sun, W., Zhang, S.B., Yang, J.S., Wei, X., Zhu, J.L., Liu, Y.J., 2017. Quality assessment of aquatic environment and fluxes of major pollutants to the Xiaoqing River estuary. Mar. Environ. Sci. 36, 366-371 (348, in Chinese, with English abstract).

Tang, Q.S., Jin, X.S., Wang, J., Zhuang, Z.M., Cui, Y., Meng, T.X., 2003. Decadal-scale variations of ecosystem productivity and control mechanisms in the Bohai Sea. Fish. Oceanogr. 12, 223-233.

Taylor, A.H., Allen, J.I., Clark, P.A., 2002. Extraction of a weak climatic signal by an ecosystem. Nature 416, 629-632.

Taylor, D.I., Oviatt, C.A., Borkman, D.G., 2011. Non-linear responses of a coastal aquatic ecosystem to large decreases in nutrient and organic loadings. Estuar. Coasts 34, 745-757.

Vörösmarty, C.J., Meybeck, M., Fekete, B., Sharma, K., Green, P., Syvitski, J.P.M., 2003. Anthropogenic sediment retention: major global impact from registered river impoundments. Glob. Planet. Chang. 39, 169-190.

Wang, Y.J., Liu, D.Y., Lee, K., Dong, Z.J., Di, B.P., Wang, Y.Q., Zhang, J.J., 2017. Impact of Water-Sediment Regulation Scheme on seasonal and spatial variations of biogeochemical factors in the Yellow River estuary. Estuar. Coast. Shelf Sci. 198, 92-105.

Wyatt, T., 2013. Margalef's mandala and phytoplankton bloom strategies. Deep-Sea Res. II $101,32-49$.

Yang, J.Q., Gao, Z.H., Cui, W.L., Zhang, H.L., Zhang, A.J., 2006. The prevention and control act on red tide in the Qingdao Olympic Sailing Competition Venue and adjacent sea area. Mar. Environ. Sci. 25, 73-78 (in Chinese, with English abstracts).

Yu, N., Yu, J.S., Lv, Z.B., Wei, Z.H., Xu, B.Q., 2012. Disaster characteristics of harmful algal bloom and its early warning management in Shandong coastal waters. Chin. J. Ecol. 31, 1272-1281 (in Chinese, with English abstract).

Yung, Y.K., Wong, C.K., Broom, M.J., Ogden, J.A., Chan, S.C.M., Leung, Y., 1997. Longterm changes in hydrography, nutrients, and phytoplankton in Tolo Harbour, Hong Kong. Hydrobiologia 352, 107-115.

Zhang, H.L., Zhang, A.J., Dou, Y.M., Zhang, H.D., 2005. The research on occurrence characteristics of red tide in Bohai sea. In: The Proceedings of Environmental Protection. China Environment Press, Beijing, pp. 72-77 (in Chinese, with English abstracts).

Zhu, G.G., Cui, Y., Han, X.X., Li, H.Y., Zhu, M.Y., Deng, J.M., Li, H.P., Chen, W.M., 2015 Response of phytoplankton to nutrient reduction in Shahe Reservoir, Taihu catchment, China. J. Freshw. Ecol. 30, 41-58. 